\title{
Explaining the uncertainty: understanding small-scale farmers' cultural beliefs and reasoning of drought causes in Gaza Province, Southern Mozambique
}

\author{
Daniela Salite $^{1}$ (D) \\ Accepted: 15 February 2019 / Published online: 19 March 2019 \\ (c) The Author(s) 2019
}

\begin{abstract}
This paper explores small-scale farmers' cultural beliefs about the causes of drought events and the reasoning behind their beliefs. Cultural beliefs vary across countries, regions, communities, and social groups; this paper takes the case of farmers from Gaza Province in southern Mozambique as its focus. Findings show that the farmers have a limited knowledge and understanding of the scientific explanation about drought. Thus, farmers' beliefs about the causes of drought are strongly based on the indigenous (the power of spirits) and Christian philosophies that attribute drought to supernatural forces, such as ancestors or God, and as a punishment for (some unknown) wrongdoings. Farmers have a distinct and under-explored repertoire of possible wrongdoings to justify the punishments driven by those cultural beliefs. Some of their reasoning is static, while some is mutable, and is based on their observation and perception of the negative, unexpected, or harmful recent or current events which happen in their surrounding environment, and which they believe could be avoided or prevented. Farmers' beliefs about drought causes, and their underlying reasoning for those beliefs, are what will primarily influence their perception of their own capacity to adapt, their motivation to respond, and their behavioral responses. Yet, their social groups exert a great influence on their choices of response. The paper concludes that more context-specific investigations into the socio-psychological nature of farmers' beliefs are required prior to interventions in order to better help farmers to respond to future drought risks.
\end{abstract}

Keywords Farmers · Drought · Cultural beliefs · God · Ancestors · Punishment

\begin{tabular}{|c|c|}
\hline \multicolumn{2}{|c|}{ Abbreviations } \\
\hline DRR & Disaster Risk Reduction \\
\hline FGD & Focus Group Discussion \\
\hline FRELIMO & $\begin{array}{l}\text { Frente de Libertação de Moçambique } \\
\text { (Mozambican Liberation Front) }\end{array}$ \\
\hline HIV & Human Immunodeficiency Virus \\
\hline IFRC & $\begin{array}{l}\text { International Federation of Red Cross and } \\
\text { Red Crescent Societies }\end{array}$ \\
\hline INGC & $\begin{array}{l}\text { Instituto Nacional de Gestão de Calamidades } \\
\text { (National Institute for Disaster Management) }\end{array}$ \\
\hline IPCC & Intergovernmental Panel on Climate Change \\
\hline MAE & $\begin{array}{l}\text { Ministério da Adminstracão Estatal (Minis- } \\
\text { try of State Administration) }\end{array}$ \\
\hline
\end{tabular}

Daniela Salite

d.1.j.salite@pgr.reading.ac.uk; danielasalite@gmail.com

1 School of Agriculture, Policy and Development, University of Reading, Whiteknights Campus, Reading RG6 6AR, UK

\author{
RENAMO Resistência Nacional Moçambicana \\ (Mozambican National Resistance) \\ SSA Sub-Saharan Africa \\ SPSS Statistical Package for Social Sciences \\ UNESCO United Nations Educational, Scientific, and \\ Cultural Organization
}

\section{Introduction}

In recent decades, the increasing threats posed by climate change and variability, and the increasing occurrence of natural disasters, especially droughts, have raised an urgent need for small-scale farmers in rain-fed areas to adapt to the negative impacts of the threats on food production, availability and security (IPCC 2007). This need for adaptation is particularly high for small-scale farmers in sub-Saharan Africa (SSA) due to their high dependence on rain-fed agriculture as their main economic activity (Wilhite et al. 2014). This is because SSA is seen as the center of occurrence for 
global drought and desertification problems (Benson and Clay 1998). Additionally, due to climate change, drought episodes in SSA are projected to increase by 2030-2040, which is expected to adversely affect crop production and reduce yields by $40-80 \%$ (World Bank 2013). Adaptation refers to a process of conscious change in individuals' systems of behavior and characteristics in order to respond to actual or expected climatic stimuli (Brooks 2003, p. 8; IPCC 2001).

In different parts of the world, governmental bodies and their development partners have been designing, planning and implementing adaptation strategies to help farmers reduce their exposure and vulnerability to climatic stimuli, and to enhance their adaptive capacity and resilience. However, most of their planned adaptation strategies have focused on technical aspects, socio-economic factors and resource constraints (Adger et al. 2007, 2009; IPCC 2007). However, changes in individuals' systems of behaviour and characteristics is a complex, heterogeneous, and continuous process that requires more than simple adjustments to the above factors (Smit and Wandel 2006). There are several other factors and conditions that may also influence behavioural change, some more hidden than others and often forgotten, such as cultural factors, which are essentially endogenous to society (Adger et al. 2009). In fact, some authors argue that the success or failure of adaptation activities are determined more by cultural factors, such as local knowledge, perception, values, beliefs and religion, than any other factor (Adger et al. 2007, 2009; Artur and Hilhorst 2012).

Cultural factors shape societal relationships with the surrounding environment, the way people identify, perceive, understand and experience risks, how they behave in relation to those risks and how they decide to respond (Ariff and Beng 2006; Farmer et al. 2012; IFRC 2014, p. 40). For example, Kahan et al. (2015), through their "Cultural Cognition Thesis', argue that the heavy reliance of individuals on cultural meanings when framing perceptions of risk can lead them to perceive and attribute risks in ways that correspond with their cultural values and beliefs. This reliance precedes fact in risk perception, and risks may therefore be dismissed if they do not fit cultural values and beliefs. At times, this selective viewpoint can represent a key factor in risk by making it meaningless, and thereby hindering people's ability to make decisions and to act. This results in farmers exposing themselves to even greater risk (Kahan et al. 2011; Persson et al. 2015; Slovic 2000).

Moreover, cultural beliefs have been increasingly recognized as crucial in adaptation to, and reduction of, the risk of disaster due to their influence on people's attitudes and behaviors towards natural hazards, on their exposure, and on their vulnerability, although this is an area that remains under-researched (e.g., IFRC 2014, p. 14; Schipper 2010). Murphy et al. (2016) and Schipper (2015, p. 146) define cultural beliefs as the underlying philosophies and ideologies that influence individuals' and communities' worldviews. Many studies exist on people's perceptions of climate change and risks, on traditional ecological knowledge, and on beliefs about the causes of natural disasters. However, emphasis is mostly given to Christian beliefs that attribute the causes of natural disasters to God (e.g., IFRC 2014, p. 11; Jarawura 2014), and to the description of diverse rainmaking ceremonies (e.g., Babane and Chauke 2015; Başgöz 2007). These studies give little explanation about people's underlying reasoning for those beliefs which make God cause natural hazards. Additionally, limited attention is given to the indigenous beliefs (the power of ancestors' spirits) people hold that help them to explain the occurrence of natural disasters, and to sometimes live with their risks. Limited attention is also given to how people's beliefs are formed, why they are followed, and the influence they exert on people's perceptions of nature, their worldviews, and their daily lives.

Therefore, this paper aims to reduce this gap in the research and to gain an understanding of farmers' cultural beliefs and reasoning about the underlying causes of drought. The paper also aims to facilitate the understanding of how the reasoning is formed, why the beliefs are followed and how they influence farmers' behavior and choices of response to drought. It is expected that the insights gained will influence the design and implementation of intervention strategies that are more culturally sensitive and successful in helping farmers to respond to future drought risks.

Since cultural beliefs are place specific, and vary across countries, regions, communities, and social groups, this paper takes, as an example, the specific case of small-scale farmers in Gaza Province, Southern Mozambique. Although, in the last 20 years, several drought events have occurred in the province that have impacted farming activities and led to problems such as famine and malnutrition (Devereux 2007; Rovere et al. 2014), the most recent drought (from 2014 to 2016) was more prolonged than farmers could remember having experienced before. Therefore, this particular event provided a unique opportunity to gain a richer knowledge and clearer understanding of the farmers' beliefs about the causes of drought. For the purposes of this study, drought is defined as an extended period (months or years), in which precipitation is less than the annual average, resulting in scarcity of water for environmental functions and human activities (Rouault and Richard 2005; Udmale et al. 2014).

The following section provides a discussion on the role of cultural beliefs in helping farmers explain the occurrence of drought events and why cultural beliefs matter in the adaptation context. The paper then describes the study site and the methods used for data collection. It subsequently explores the diverse indigenous and Christian beliefs that farmers in the study sites hold and which relate to the occurrence of drought and the reasonings behind those beliefs. It also explores the dynamics of their beliefs and the factors which 
drive them. Lastly, the paper reflects on how farmers' beliefs and reasoning are formed, why they are followed and how they influence farmers' decision-making process, motivation to act, and responses to drought.

\section{Why cultural beliefs matter in an adaptation context}

Traditional religion has shaped the culture of African societies over millennia, affecting all aspects of daily life, from economic activities to the food people eat, the way they live, dress, educate their children, treat disease, and bury their deceased kin. Whatever happens, it is possible to find an explanation that is religiously grounded (Christian 2014; Mbiti 2015, p. 8). Cultural beliefs have also historically played a crucial role in helping farmers explain the occurrence of drought and to cope with its impact.

Most African societies continue to closely associate the changes in their environments with supernatural forces, including ancestors, spirits, and God (Dei 1994; Schipper 2010). On the one hand, they believe that almost everything in the natural environment is infused with spiritual meanings that give power and significance to their actions, and with which they establish contact through ancestor worship. They venerate their ancestors because they believe they are constantly observing their living kin and, through their power are guiding their activities and behavior while protecting them against adversity, including natural disasters and illness, and believed misfortunes to be caused by evil spirits (Christian 2014; Dei 1994).

On the other hand, African societies also view weather as a phenomenon controlled by God who is seen as the creator of the universe, the omniscient, and at the apex of everything, overseeing, regulating, sustaining, and upholding all activity in the universe to allow its continuity (Golo and Yaro 2013; Mawere 2011, p. 40). Religion is one of the world's oldest and most enduring social institutions, directly influencing more than two-thirds of the global population (Haluza-DeLay 2014). According to Mbiti (2015, p. 8), religion constitutes the richest part of African heritage. Schipper (2010, p. 378) defines religion as "all forms of belief systems shared among individuals and groups based on spirituality, mysticism, and faith in divinity, enshrined in formal institutions, in organized religions, and expressed in devolved form through superstitions, mythology and folktales".

Although African societies see both ancestors and God as protectors, they also believe that they will be punished by them for any deviation from social norms and moral codes, for inappropriate behavior (Dei 1994; Fountain et al. 2004; Johnson 2005), or for a sin committed against them or the environment (Ngara and Mangizvo 2013). Thus, they use these beliefs to explain the occurrence of natural disasters, such as drought. Although historically different religions fully expect recompense or punishment from God for behaving in a good or bad way in this life, or after death in heaven or hell, the expectation of payback is, to some extent, integral to human nature and mind independent of religious beliefs (Johnson 2016, pp. 3-4). Hence, it is argued that as societies fear punishment, it is this fear that acts as a mechanism for them to reinforce the importance of respecting their culture, behaving according to their cultural norms or moral codes, and thus ensuring its maintenance (Johnson 2005).

As a result of human dislike of uncertainty and unknowns (IFRC 2014, p. 41), and because in their cultural beliefs adversity and disasters do not happen without a cause (Christian 2014), people find diverse ranges of reasoning to justify punishment from supernatural forces. For instance, some people blame human beings for practicing black magic (IFRC 2014, p. 11; Lewis and Russell 2016; Orlove et al. 2010), while others specifically blame younger generations for behaving inappropriately and committing adultery (Boillat and Berkes 2013; Jarawura 2014). Therefore, younger generations are accused of ruining religion by not upholding values, or by being less religious than previous generations. This is because the victims of natural disasters often do not perceive the events as 'natural', thus they tend to assign primary responsibility to human actions or inactions (Kumagai et al. 2006).

While some people exclusively hold a single type of belief, others may hold both indigenous and Christian beliefs concurrently in the hope that if one fails, they can still count on the other (Murphy et al. 2016; Pew Forum 2010; Roncoli et al. 2002). Additionally, Murphy et al. (2016) found that some church leaders, such as in the Bolero community in Malawi, encourage churchgoers to pursue both indigenous and Christian beliefs as they recognize the importance of respecting indigenous beliefs and preserving their culture. However, they also noted that such encouragement was given because the church leaders have shared leadership roles by also being the community headmen.

On the other hand, besides the co-existence of two types of beliefs, people may also shift their beliefs. For instance, in SSA and in the South-Pacific, a shift has been noted from Indigenous to Christian beliefs with increased numbers of Christians (IFRC 2014, p. 11; Murphy et al. 2016). Although people may now rely more on Christianity to provide them with direction, purpose and meanings to their lives, they may also question their faith and abandon it because of feeling betrayed or abandoned by God in circumstances they believe required his divine intervention, such as during the occurrence of natural disasters. This disappointment with a capricious God may lead people to feel isolated and have a sense of estrangement from their community or social group (Wilson and Moran 1998). Such shifts show that societies' beliefs are not static, rather they may vary according to circumstances. 
However, the effects of these shifting beliefs on adaptation are still not well understood (Murphy et al. 2016).

Societies' widespread beliefs that droughts are caused by uncontrollable and compelling supernatural forces (Roncoli et al. 2009; Slegers 2008), may lead them to implement responses which ask for forgiveness, make peace with these supernatural forces, and ask for rain through the performance of traditional ceremonies or prayers. These kinds of responses may stop societies from taking the most appropriate measures and may in fact increase their vulnerability to drought risks (IFRC 2014, p. 37). It is also argued that their beliefs may block the uptake of scientific information or technological responses if they are not transmitted in a way that is acceptable to the intended beneficiaries (Kahan et al. 2007, p. 497). Indeed, not attempting to understand the nature and importance of cultural beliefs and include them in current polices and technological adaptation strategies has been highlighted as one of the causes of the lower than expected, or maladaptive outcomes, of adaptation strategies (Adger et al. 2013; Kuehne 2014; Schipper and Dekens 2009). One example of failure was given by IFRC (2014, p. 121) concerning some current policies and programs operating in the Pacific.

People are more likely to take part in, and remain committed to, adaptation actions with which they identify and are directly connected to, which correspond to their needs, and which preserve and promote their culture. Thus, involving communities in the identification of their vulnerabilities, needs, priorities, and their existing and effective strategies used to respond to environmental, weather, and climatic stressors, is crucial to encourage their participation as it empowers them to take action and to lead others (Lebel 2013; Shaw et al. 2008; Sheil et al. 2006). Moreover, as adaptation requires joint efforts to mediate collective risks, communities' shared or normative beliefs about the causes of a stressor can act as a starting point for collective action against it, can promote their cohesion, and can also increase their social resilience (Adger 2003; Jones 2011; Leck et al. 2011). People share the belief that working together is efficacious to the achievement of their aims (Bandura 1998). Thus, cultural beliefs have been increasingly recognized as both a facilitator and an inhibitor of adaptation to environmental and climate change, and thus are a crucial part of any context of Disaster Risk Reduction (DRR). The following section builds on these ideas by exploring the role of cultural beliefs in the context of small-scale, rain-fed farming in Gaza Province in Southern Mozambique.

\section{Methods and procedures}

\section{Study site}

Mozambique is one of the most vulnerable countries in the world to natural disasters and climate change (INGC 2009), and drought constitutes the most common and devastating natural hazard. The southern region of the country is especially susceptible to regular drought, and in Gaza Province drought occurs in 7 out of every 10 years (Kyle 2003; Uaiene 2008). The study was conducted in two districts extremely vulnerable to drought, Chibuto and Guija, in the southern province of Gaza (Fig. 1). Both districts are in the southwestern part of the province, in the watershed of the Limpopo river basin, which is one of the main rivers in the country. Small-scale, rain-fed subsistence farming is the main economic activity in both districts, and the main cultivated crops are maize and beans (butter and cowpea). However, annual rainfall is low and irregular, varying between 400 and $600 \mathrm{~mm}$, which makes rain-fed agriculture very challenging, and sometimes leads to food insecurity problems. The rainfall period is usually from October to April with a mid-season dry spell often occurring during this period and falling during critical periods of crop growth (Brito et al. 2009). Chibuto has a tropical arid climate, and annual mean temperature of above $25^{\circ} \mathrm{C}$, while Guija's climate is tropical dry to semi-arid, with annual mean temperatures of between 25 and $26{ }^{\circ} \mathrm{C}$. These climatic conditions, when combined with poverty make farmers extremely vulnerable to drought.

Illiteracy levels remain very high in Chibuto (54\%) and Guija (70\%) districts, mostly among women who also constitute the majority of the population there (MAE 2005). This is a result of poor state investment in rural education after the end of independence war (1964-1974) and civil war (1977-1992) in Mozambique (UNESCO 2015). Although Portuguese is the official language of the country, it is spoken by only $37 \%$ of the population in Chibuto and $24 \%$ in Guija (MAE 2005). The most commonly spoken language is Xitsonga, which is a southern African Bantu language spoken by the Tsonga people. Within Xitsonga, the most spoken dialect is Changana (Shangaan, Shangani). Most inhabitants are religious, i.e., practice or believe in a religion. Although Christianity and Islam are the most widespread religions in SSA, a recent change of religion has occurred in most parts of the region, including in Mozambique. This change of Christianity and Islam religions was marked by the rapid increase of diverse Pentecostal Charismatic Churches, such as Assembly of God, Apostolic faith, and the Zionist movement (Meyer 2004). In the study site, the Zion church is the most frequented, followed by the Catholic church (MAE 2005). However, especially in the rural areas, ancestral spirit worship continues to play an important role, and is reflected in diverse ways such as through the annual performance of various types of traditional ceremonies.

\section{Methods}

This study used a mixture of qualitative and quantitative methods to collect and analyze the data. Although the 
MOZA M B I Q U E

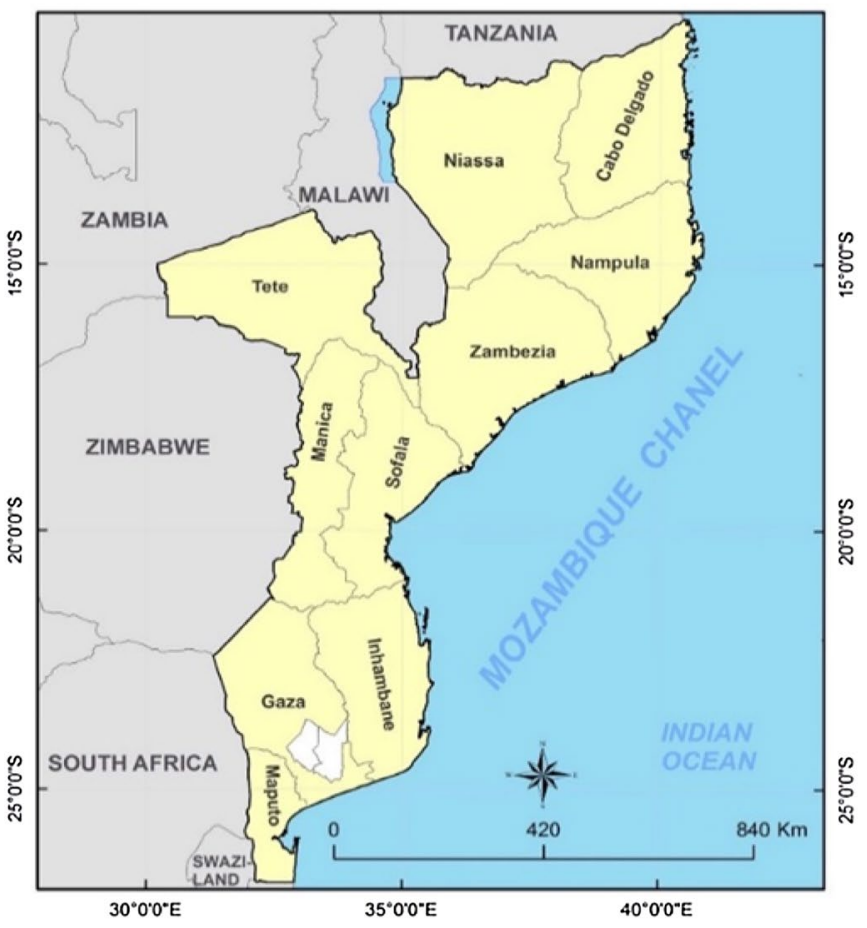

CHIBUTO

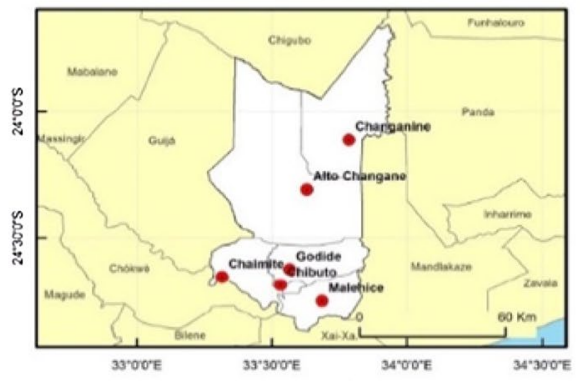

GUIJÁ

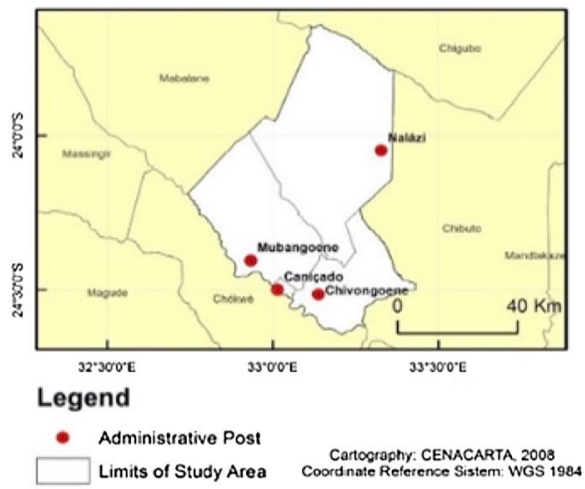

Fig. 1 Location of the study site in Gaza Province, southern Mozambique

approach is mostly inductive, interpretive and explanatory in nature, which are key characteristics of qualitative studies, the use of both qualitative and quantitative methods was crucial to triangulate and validate the data and the findings through cross-comparison. The study was conducted between April and September 2017. During data collection, open-ended questionnaires and Focus Group Discussions (FGDs) were used to gain a clear, rich, and holistic understanding of diverse individual and collective cultural beliefs about drought causes. Open-ended questions allow participants to have more freedom to express their viewpoints because they do not provide a defined set of alternative answers. Since the majority of the participants only spoke Changana, the data was collected by me, with help from a translator from Changana to Portuguese. To ensure the complete capture of participants' responses, the interactions with them were audio recorded, and first manually transcribed by me, then transcribed to Microsoft Word by myself and two transcribers.

One hundred questionnaires were delivered at household level for each district (50 per community), totaling 200 . The questionnaires included both genders (male and female), and three age groups (16-24; $25-44$ and over 45 years old). Of the participants, around $4.5 \%$ belonged to first age group, $41.5 \%$ to the second, and $30 \%$ to the last. The remaining $24 \%$ did not know their ages and did not have any type of identification, which is a result of years of Portuguese colonialism, followed by independence and civil wars. However, judging by their facial features and ages of their descendants they could be grouped as 45 years old or over. The majority of the participants were women $(76 \%)$, which reflected the general scenario of the inhabitants of the province due to reasons such as male labor migration to South Africa, or to other parts of the country. The questionnaire collected detailed information on participants' demographic structure, education level, livelihood strategies and networks, assets, the natural, the physical and social capital. The questionnaire also collected information on participants' perceptions of the causes, impacts and responses to drought, and the insights obtained were explored further during the FGDs.

A total of 25 FGDs (13 in Chibuto and 12 in Guija) of around six to eight participants were formed according to their gender and age groups mentioned above (three age groups per gender). The group discussions explored participants' beliefs, behaviors and practices, and how these have changed over time as a consequence of the unpredictability of weather and climate. The rationale for putting together people from the same gender and age group was to make them feel less constrained to talk in front of each other, to make the discussion more fruitful and, consequently, to generate more data. Additionally, gender and age differentiation between the FGDs allowed exploration of in-depth 
similarities and differences in people's beliefs, as these are some of the attributes that are generally deemed to shape individual's beliefs and their interpretation of, as well as their attitudes and responses to risks (Gaillard 2007; Leck et al. 2011).

A free-listing technique was used in both the questionnaires and the FGDs to list participants' beliefs about drought causes, their perceptions and observations of climate changes, and to quantify the relative importance that participants gave to their answers. Free-listing is a technique that is exploratory in nature, aiming to obtain a list of items within a cultural domain and to determine their prominence and relative importance (Weller 1998). The technique assumes that the items mentioned first and most frequently by the participants are the most significant (Campos et al. 2014). The study also used a narrative-type inquiry to explore in depth the life histories of participants' experiences of drought events and their explanations about their beliefs of its causes. This type of inquiry is useful to collect information related to events, happenings, human activities, meanings of key events in people's lives at individual and collective levels, and the cultural context in which they live. It uses narrative analytic procedures to generate stories that are explanatory (Flick and Gibbs 2007, p. 56).

A coding scheme was developed for both the questionnaires and the FGDs to ease the process of comparison, to help classify, organize, and categorize the data according to the similarities (agreement, partial agreement, silence, or dissonance) and to analyze them. After the development of codes, themes were created to analyze the qualitative data (FGDs) using NVivo. The themes facilitated the comprehension, comparison and contrasting of the data, as well as the calculation of the reference (number of evidences within the theme), and the generation of theory. The quantitative data was analyzed using SPSS (Statistical Package for Social Sciences), and involved descriptive statistics, specifically, cross tabulations to discern the interrelation and interaction between the variables being analyzed, compare and contrast them and calculate their percentages.

\section{Results}

In this section, the paper explores farmers' beliefs about drought and the reasoning behind their beliefs about the occurrence of drought. This is followed by examination of the dynamics of farmers' beliefs and the factors that drive them.

\section{Farmers beliefs and reasoning of drought causes}

During FGDs and in the individual questionnaires, farmers were asked about their beliefs of the causes of drought events in their communities. Responses showed that participants have a limited knowledge and understanding of the scientific explanation for drought and climate change, and they mostly began to hear about it during the last drought (2014-2016) via the radio and announcements by local authorities at their general community meetings. Most of the participants are illiterate (36.5\%), $79.5 \%$ of them being women, or have only attended primary school $(52.5 \%)$, which is why many are unfamiliar with the scientific explanations for drought. On the one hand, these illiterate participants related climate change to changes in their socio-cultural environment by giving examples of the current behaviour of young people, which is dissimilar to the past. Participants asserted that nowadays young people are disrespectful to adults and have children when they are around 12 years old. On the other hand, participants related drought to the El Niño phenomenon, a warming of the sea surface temperature, which causes drought in Southern Africa and other parts of the world. However, because participants only heard about El Niño during the last drought, they struggled to pronounce the name and referred to El Niño as aluminum (due to the similar pronunciation in Portuguese), an ice stone or an animal which is in the ocean blocking the rain, asserting that it will rain when the animal dies.

The young people (16-24-year old), who have more access to education up to lower secondary school, were the ones who tended to talk about drought-related scientific information as part of their own knowledge. For example, young people mostly mentioned about the impacts of their activities on the changes in weather and climate, such as cutting down trees and burning them to clean fields, grow crops or produce charcoal. Despite such explanations, these young participants claimed that there was nothing they could do since they depend on their activities for their livelihoods and survival. Tambo (2010) also correlated low levels of education to farmers' weak understanding of scientific information about drought events. Conversely, the majority of farmers (63.5\%) hold a variety of cultural beliefs about the causes of drought that range from indigenous to Christian, which can sometimes be exclusive, or a mixture of both types of beliefs as a result of their uncertainty of the causes. There were also some farmers who were unsure (9\%), or claimed not to know what could be the possible causes of drought (23.5\%). Some farmers also showed shifting beliefs, voluntarily or involuntarily, as a result of perceived social group pressure.

\section{Christian beliefs}

In both study sites, $51 \%$ of the individual farmers who were surveyed stated that drought is caused by God, while this was mentioned by 5 out of 25 FGDs (Chibuto only) (see Table 1). Most participants are Christians (72.5\%) and they attend different types of churches, with the Catholic (17\%) 
and Zion (32\%) churches being the most attended ones in Chibuto and Guija, respectively (Fig. 2). Women constitute the majority of Christian members of the community, representing $80 \%$ of them.

The most predominant argument in both the individual questionnaires and the FGDs was that God created nature and also controls it. Since the rain comes from the sky, God is the only one who has the power to stop it and to decide when it should or should not rain. This is why we pray to
Him and ask for the rain and for other needs. This explanation resonates with the traditional way participants refer to God in their Changana dialect, "Xikwembo", which means "father of everything in the realm of existence" (Mawere 2011, p. 40). The sovereignty of God was even recognised by almost half of $27.5 \%$ non-Christian people. Yet, when asked why then they think God, with his omnipotence, is stopping the rain, their justifications were vague. Individually, the majority of them did not know the underlying reasons,

Table 1 Responses related to Christian beliefs given during the fieldwork ( $n=200$ questionnaires; $n=25$ FGD)

\begin{tabular}{|c|c|c|}
\hline Explanations of drought related to Christian beliefs & Study site & Number of references $^{\mathrm{a}}$ \\
\hline We do not know how to explain it, we just know it is god & Chibuto, Guija & Questionnaire (32) \\
\hline $\begin{array}{l}\text { The rain belongs to god and he is the only one who has the power to stop the rain, not a human being. } \\
\text { Therefore, we pray for him asking for the rain, although our requests are not always met }\end{array}$ & Chibuto, Guija & Questionnaire (27) \\
\hline God controls nature, including the rain. He created nature and put human beings on it & $\begin{array}{l}\text { Chibuto } \\
\text { Chibuto, Guija }\end{array}$ & $\begin{array}{l}\text { FGD (1) } \\
\text { Questionnaire (22) }\end{array}$ \\
\hline $\begin{array}{l}\text { God forgot about us, that's why he is not sending rain, but we do not know what we have done to make } \\
\text { him forget about us }\end{array}$ & $\begin{array}{l}\text { Chibuto } \\
\text { Chibuto, Guija }\end{array}$ & $\begin{array}{l}\text { FGD (1) } \\
\text { Questionnaire (17) }\end{array}$ \\
\hline $\begin{array}{l}\text { God controls the rain and decides when it should rain, even when we make traditional ceremonies it } \\
\text { will not result if god doesn't want to send rain at that moment }\end{array}$ & Chibuto, Guija & Questionnaire (17) \\
\hline $\begin{array}{l}\text { God is punishing us for doing unnecessary abortions, since it is considered a sin. Also, for doing it } \\
\text { without the elders' consent }\end{array}$ & Chibuto & FGD (2) \\
\hline $\begin{array}{l}\text { God is punishing us for being ungrateful, i.e., we do not thank him for the good harvest we have when } \\
\text { he sends the rain. What is more, to make things worse, instead of thanking him we thank our ances- } \\
\text { tors for the good harvest }\end{array}$ & Chibuto & FGD (1) \\
\hline We do not know why god it is not sending rain, since it is not raining in other areas as well & Chibuto & FGD (1) \\
\hline The rain comes from the sky & Guija & Questionnaire (2) \\
\hline God regulates the rain, he is now giving rain to other zones and then will give it to us & Chibuto & Questionnaire (2) \\
\hline God is not sending rain because he gave up on us & Chibuto & Questionnaire (2) \\
\hline God is not sending rain because of the war in the country & Chibuto & Questionnaire (1) \\
\hline
\end{tabular}

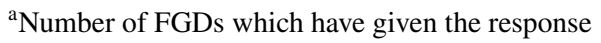

\section{TYPE OF FREQUENTED CHURCH IN CHIBUTO DISTRICT (\%)}

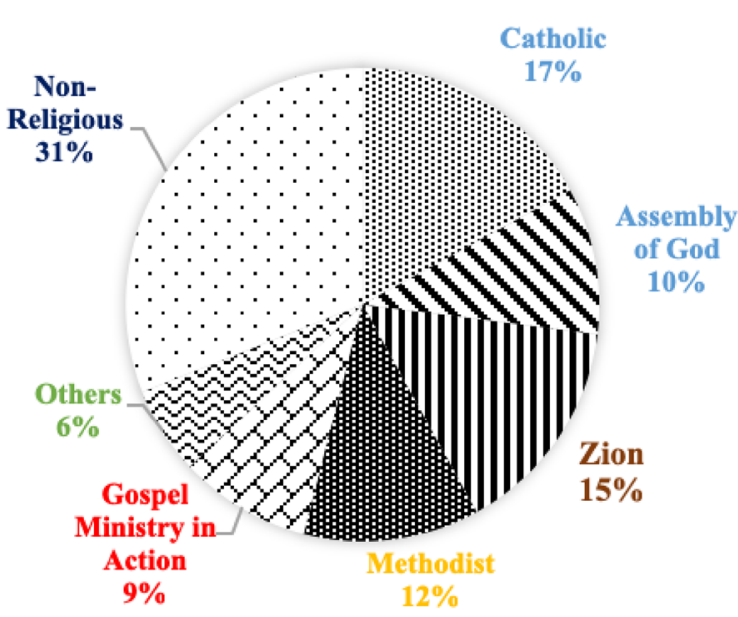

\section{TYPE OF FREQUENTED CHURCH IN GUIJA DISTRICT (\%)}

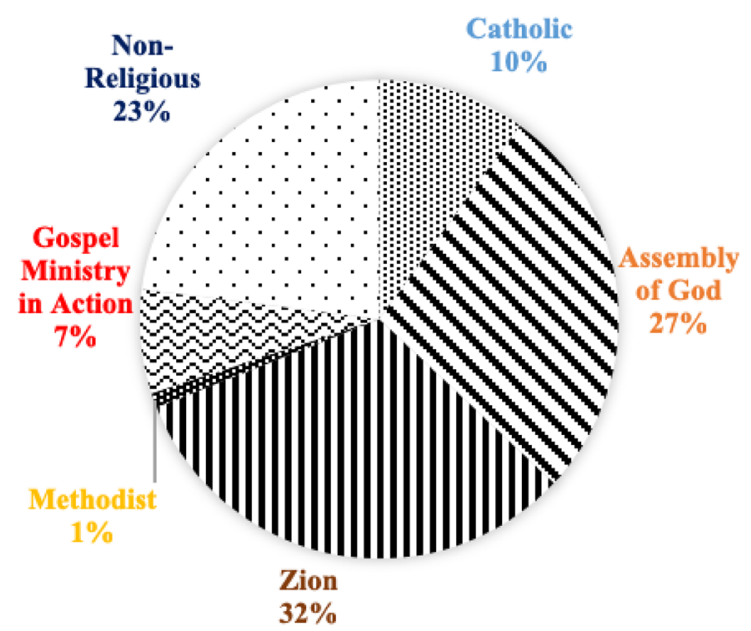

Fig. 2 Most frequented churches in Chibuto (left) and Guija (right) districts ( $n=100$ participants per district—source: author's compilation) 
they just knew that it was God because of his omnipotence. Others argued in vague terms that God simply forgot about them, or gave up on them for some unknown reason or for sins they believed they might have unsconsciously committed. Similar responses were given by the FGD.

However, two individual farmers and one FGD from Chibuto seemed to have a different answer to the others, which was found after analysing what was going on in the country. A 48 years old female farmer who attends the Methodist church concluded that: "since it is not possible to rain everywhere at the same time, God was being fair to everyone by giving, at times of drought, rain to other zones, before giving rain to our zone". Consistent with findings from Robinson (2009, p. 62), the other farmer, a 65 year old non-Christian man, believed that: "God was causing drought because of the war in the country." This belief was related to the recent political instability in the country caused by a conflict between the main opposition party (RENAMO) and the ruling party (FRELIMO), that lasted from October 2014 to the end of 2016. This resulted in RENAMO armed militia attacking national roads and rail traffic in the center of the country, killing a large, undisclosed number of civilians. Conversely, a group of over- 45 years old women recognized that everyone was guilty of causing the punishment for being ungrateful, of not thanking God for the good harvest that they have when he sends rain, and thanking their ancestors instead.

\section{Indigenous beliefs}

For generations, oral traditions have played a crucial role in societies as the primary vehicle of history, transmission of knowledge and for the teaching of important aspects of local culture (e.g., social norms, customs, beliefs, and moral values) (Sumner 2013, p. 9). Although drought as a punishment from ancestors was less prevalent in terms of individual beliefs (12.5\%), when compared to group beliefs (100\%), participants believed their ancestors were punishing them with drought for not following and respecting their customs as in the past. A decline in individuals' indigenous beliefs has been registered across sub-Saharan Africa (Pew Forum 2010), but as such beliefs are condemned by Christian and Muslim groups, people are very hesitant to discuss them (Orlove et al. 2010). Participants provided a variety of justifications about why they have not been following and respecting tradition (see Table 2 for complete explanations), which were categorized into four groups: failure to undertake rituals correctly; unnecessary abortion; unburied dead bodies; and witchcraft. It was noted that individuals' indigenous drought beliefs were mostly verified among those non-religious participants who had little (primary school) or no education.

\section{Rituals}

Rituals are the primary mechanism through which communities maintain beliefs among their members (Sanderson 2008), and participants in southern Mozambique showed that their communities were no exception to this as they linked drought to non-frequent realization of certain rituals. Some FGDs (10 out of 25), and a few individuals who took the questionnaire (4\%), linked drought to traditional ceremonies. Most of these individual participants were over 45 years old. The common belief in both study sites was that the present-day non-realization of traditional ceremonies, which were performed regularly in the past, was the underlying reason for punishment by their ancestors. Currently, such ceremonies are only performed when they perceive long delays to the start of the rainy season.

As part of participants' tradition, diverse types of traditional ceremonies have been performed throughout the year in their communities. Some are specific ceremonies to ask for rain, called 'Mbelelo', whereas others are for diverse motives, but are also used as an opportunity to ask their ancestors for rain. One such ceremony is called 'Pfupfanhe', which is intended to chase away crop pests. Additionally, participants from Guija believed that traditional ceremonies are fruitless, and that drought persists when they are not performed correctly, especially when they are not performed by people who are part of the native family of the community, of which their leader is part. The value of traditional rain-making ceremonies has also been recognized by other communities in other parts of the world where the rain has been inadequate, such as Iranian settled agriculturalists, and South African and Nigerian tribes (Başgöz 2007; Haruna 1997; Semenya 2013).

In addition to explanations related to traditional ceremonies, participants from Guija district strongly believed that drought was related to people not following the correct rituals when burying people who had died from tuberculosis (5FGDs), or who had dreadlocks (3FGDs) in order to release their souls and avoid misfortune. Mozambique has a significant incidence of tuberculosis (37\%) which is mostly related to Human Immunodeficiency Virus (HIV), and there are higher mortality rates in rural areas due to factors such as lack of diagnosis and poor access to healthcare (WikmanJorgensen et al. 2015). Participants explained that, before burying a person who died from tuberculosis, the ritual must start in their homes. If the person was living alone, the ritual includes burning, inside the house, the grass that forms the core of its ceiling together with a traditional plant, eggshells, salt, and a bit of the house rubbish. The smoke created serves to partially release the soul of the deceased person. In other cases, a simple ritual of housecleaning is followed, and a traditional tea must be served to all household members. After that, when burying the person, the sand 
Table 2 Responses related to Indigenous beliefs given during the fieldwork ( $n=200$ questionnaires; $n=25$ FGD)

\begin{tabular}{|c|c|c|c|}
\hline Category of indigenous beliefs & Explanation & Study site & Number of references \\
\hline \multicolumn{4}{|l|}{ Rituals } \\
\hline \multirow[t]{5}{*}{ Traditional rain ceremony } & $\begin{array}{l}\text { Not making traditional ceremonies regularly as we used to do in the } \\
\text { past. Now we just do it when we feel delay in the start of the rain- } \\
\text { ing season, therefore we are punished by our ancestors }\end{array}$ & Chibuto and Guija & $\begin{array}{l}\text { FGD (5) } \\
\text { Questionnaire (3) }\end{array}$ \\
\hline & $\begin{array}{l}\text { When the traditional ceremony is not performed by people who are } \\
\text { part of the native family of the community }\end{array}$ & Guija & $\begin{array}{l}\text { FGD (2) } \\
\text { Questionnaire (4) }\end{array}$ \\
\hline & $\begin{array}{l}\text { Not making traditional ceremonies regularly to eliminate crop pests, } \\
\text { since this ceremony also serves to ask for the rain and always have } \\
\text { positive results }\end{array}$ & Chibuto & $\begin{array}{l}\text { FGD (1) } \\
\text { Questionnaire (1) }\end{array}$ \\
\hline & $\begin{array}{l}\text { When people performing the ceremony do not follow the norms of } \\
\text { the community and do not do everything requested by the ances- } \\
\text { tors }\end{array}$ & Guija & FGD (1) \\
\hline & $\begin{array}{l}\text { The family of the native ancestors are not taking care of them, are } \\
\text { not doing what they want such as the performance of traditional } \\
\text { ceremony, therefore they are furious and are punishing us by not } \\
\text { sending the rain }\end{array}$ & Guija & FGD (1) \\
\hline Coupling rituals & $\begin{array}{l}\text { When a man sleeps with a widow, and on the following day, they do } \\
\text { not undergo the required ritual }\end{array}$ & Guija & FGD (1) \\
\hline \multirow[t]{4}{*}{ Burying rituals } & $\begin{array}{l}\text { When someone dies from tuberculosis and is not buried according } \\
\text { to the tradition to release their souls }\end{array}$ & Guija & FGD (5) \\
\hline & $\begin{array}{l}\text { When someone who had dreadlocks is buried without them first } \\
\text { being cut }\end{array}$ & Guija & FGD (3) \\
\hline & $\begin{array}{l}\text { When a woman dies while pregnant and is not buried according to } \\
\text { the tradition, i.e., a slight tear must be made in the belly to remove } \\
\text { air and the person must be buried in the lower part of the lake and } \\
\text { not in the cemetery }\end{array}$ & Guija & FGD (1) \\
\hline & $\begin{array}{l}\text { When a woman dies before having a child and is not buried accord- } \\
\text { ing to the tradition, i.e., when burying her, her chest region must } \\
\text { not be covered by sand, but a plastic basin must be placed there } \\
\text { to release her soul. Moreover, a sharp stick must be stuck in the } \\
\text { ground outside her house }\end{array}$ & Guija & FGD (1) \\
\hline Unnecessary abortion & Unnecessary abortion without the elders' consent & Chibuto and Guija & $\begin{array}{l}\text { FGD (23) } \\
\text { Questionnaire (19) }\end{array}$ \\
\hline Unburied dead bodies & $\begin{array}{l}\text { When the bones, mainly the teeth, of dead bodies get exposed they } \\
\text { shock the lightning, stopping the rain from falling. Therefore, in } \\
\text { order to avoid that, they must be buried again }\end{array}$ & Chibuto and Guija & FGD (4) \\
\hline \multirow[t]{6}{*}{ Witchcraft } & $\begin{array}{l}\text { When the witchdoctors invoke spirits that are not from the area } \\
\text { when doing their activities }\end{array}$ & Guija & $\begin{array}{l}\text { FGD (2) } \\
\text { Questionnaire (2) }\end{array}$ \\
\hline & $\begin{array}{l}\text { Indian food traders in the town are stopping the rain to impede us } \\
\text { from producing food, and so buy from them }\end{array}$ & Chibuto & FGD (1) \\
\hline & $\begin{array}{l}\text { Road workers stop the rain to allow them to do and finish their } \\
\text { works without interruption }\end{array}$ & Guija & FGD (1) \\
\hline & $\begin{array}{l}\text { I know a lady here in the community who stops the rain, but I prefer } \\
\text { to not to talk about it }\end{array}$ & Chibuto & Questionnaire (1) \\
\hline & $\begin{array}{l}\text { Fishermen who wants salty fish for selling, so the fish quickly dry } \\
\text { up }\end{array}$ & Chibuto & Questionnaire (1) \\
\hline & $\begin{array}{l}\text { Commercial farmers with access to irrigation are blocking the rain, } \\
\text { so they can be the only ones producing }\end{array}$ & Chibuto & Questionnaire (1) \\
\hline
\end{tabular}

grave must be leveled off instead of being given the usual oval shape which allows the rain to run off, as the former shape facilitates the release of the soul. Additionally, the person must be buried in the lower part of the lake, not in the cemetery as usual. Although family backyards, burial places, or cemeteries are the most common places to bury corpses in Africa (Mbiti 2015, p. 114), other less common burial places, such as the rivers, running streams, and the river or sea, have also been used in other parts of the world, such as in Iraq and India. This is a result of the belief that running water has a sacred power of purification of humans' souls, thus, acting as an effective mechanism to cleanse humans 
of their sins, and reduce the punishment in the other world (Oestigaard 2005, p. 13).

Participants from Guija also explained that when someone who has dreadlocks dies, their dreadlocks must be cut off before they are buried. This belief was reinforced during the last drought when a member of the native family of the community, and who had dreadlocks, died. Before his death, he asked his family to cut off his dreadlocks, but they did not do so. Since there was no rain in the community for a long period, after this the inhabitants started to speculate and to believe that this was the reason behind the lack of rain. Thus, feeling pressure from the community, his family decided to exhume him and cut off his dreadlocks. According to the participants, after that it did not take long for the rain to start. Mbiti (2015, p. 120) explains that most Africans believe that when someone makes demands before they die that can be fulfilled, they must be met, otherwise their spirit will not stay quiet and rest in peace. In fact, in Mozambique, it is common to see people requesting to be buried in their hometown or city, and their families achieving the 'impossible' in order to attend to their request against the fear of bringing misfortune into their lives. Sometimes, even after attending to the deceased's request, if misfortune occurs, they revert to witchcraft in the belief that something went wrong during the process. As the witchdoctors are believed to communicate with dead people, they are given the mission to discover what went wrong so that it can be corrected.

\section{Witchcraft}

Witchcraft is considered an integral part of traditional African societies, a way of life, and is believed by around 80-90\% of people (Weese 2016). Although, these societies often credit witches for causing malevolent events, such as diseases, natural disasters and death (Lewis and Russell 2016), in the study sites such attribution was not so popular in relation to the causes of drought. Only $1.5 \%$ of male individual farmers (over 45 years old) and two male FGDs (16-24 and 25-44 years old) stated that witchcraft was related to drought occurrence in their communities. In Guija, the general belief was that witchdoctors are responsible for drought as they invoke spirits that are not from the area when carrying out their activities to treat clients when they should only invoke the spirits of their ancestors. In Chibuto, it was believed that some people who benefit from drought, by being able to uninterruptedly do their work, are responsible for drought through witchcraft, such as the Indian food traders in the town and commercial farmers who have access to irrigation. Their perception was that Indian food traders were stopping the rain to allow them to sell more of their products because the farmers could not produce their own food and would be forced to buy from them. Participants gave examples of how they confirmed their theory during the last drought when the traders came to their community to sell their products and the inhabitants were forced to buy from the traders because they had no production surplus. Similar reasoning was also applied when explaining that commercial farmers who have access to irrigation could stop the rain to ensure they were the only ones producing in the area, and therefore ensuring a market for their harvest.

\section{Co-existence of and shifts in beliefs}

Some participants who completed the questionnaire (2.5\%), and two of the FGDs, believed that drought was a concurrent punishment from both ancestors and God due to unnecessary abortions by young people. From one perspective, participants see abortion as a sin through God's eyes, and one that must never be committed. From another perspective, abortion is also seen as a wrong and unacceptable action according to participants' cultural values, and that this kind of behavior is sanctioned by their ancestors. Therefore, to avoid sanctions, young women who become pregnant secretly, or who have unwanted pregnancies, must ask for the elders' consent prior to having an abortion. Elders are the carriers and guardians of oral traditions and are respected for their wisdom and perceived proximity to the ancestors (Dei 1994).

The elders are then the ones who organize a ritual, with the fetus corpse present, to inform the ancestors of the abortion, and to prepare the corpse for burial in the lower part of the lake in accordance with their tradition, where they also bury people who die from Tuberculosis. Additionally, the woman's genitals are 'purified' with a traditional medication that has a burning sensation, thus also serving as a punishment for her actions. However, in cases where the person who performed the abortion is unknown, all women of reproductive age must have their genitals 'purified', as happened during the last drought in Magondzwene community in Chibuto. According to some female groups (16-24 and over 45 years old), after this general abortion ceremony it started to rain in the community.

The co-existence of indigenous and Christian beliefs was also noticed among some participants who believed that drought was occurring due to the non-frequent realization of diverse types of traditional ceremonies. They explained that, even though the traditional ceremony to ask for rain is directed towards their ancestors, God is the one who ultimately controls the rain, and because their ancestors are in heaven then they will directly transmit their rain request to God to help it to be fulfilled. Thus, their ancestors serve as the medium through which their needs are transmitted to God.

In addition, similar to findings from IFRC (2014, p. 11), a shift in beliefs from indigenous to Christian was also noticed among some of the participants. They reported that 
some churches, such as Zion, Gospel Ministry in Action, Assembly of God, and Old Apostolic, made them choose between the two types of beliefs. According to participants the church leaders argued that when someone starts attending the church then they must forget about the worship of ancestors and only follow God and his words. It is not possible to follow two pathways simultaneously, otherwise they will walk in the darkness and become lost. However, such claims, which oppose findings from Murphy et al. (2016) in Bolero in Malawi where the church leaders encourage churchgoers to pursue both indigenous and Christian beliefs, were denied by the church leaders. Meanwhile, others have argued that they have voluntarily changed their beliefs based on their perception and understanding of the disadvantages or problems which arise when following tradition. This position is exemplified by an over 45 years old woman from Guija when answering the questionnaire:

I no longer follow tradition because I go to the church, and also because the last time I participated in a traditional ceremony to chase away crop pests in 2005, I returned home with my feet aching, and it did not get better since then. I think it was God who punished me because of all the yelling and insulting we normally do during the ceremony in order to chase away the pests. God does not like or want to see people yelling and insulting.

Conversely, there were also people who reported having abandoned Christianity as they had lost hope and trust in God, as exemplified by a 68 years old woman from Guija who answered the questionnaire: I stopped going to church after the death of my sons since I felt that I did not deserve such pain for being Christian, going frequently to church and following God's words. Notwithstanding, some participants explained that abandoning Christianity allowed them to participate again in traditional rainmaking ceremonies, which was forbidden by the churches they followed. Moreover, participants explained that, despite their disappointment, they are considering returning to the church one day, as they fear not having a blessed funeral or not going to heaven when they die.

\section{Discussion and conclusion}

This study has explored small-scale farmers' cultural beliefs about the occurrence of drought, which constitutes one of the major stressors to their rain-fed agricultural activities, and the reasoning behind their beliefs. The results show that farmers mostly rely on indigenous and Christian beliefs to explain the occurrence of drought. Farmers have limited knowledge and understanding of the scientific explanation for drought due to low levels, or a lack, of education. Thus, in this study, younger people, who have more access to education (second-degree primary school and lower secondary school) and more contact with the external "world", were the ones who tended to mention this. The study also found that due to their uncertainty in their beliefs, farmers may simultaneously have different types of beliefs. Farmers' beliefs are also dynamic, since farmers may voluntarily shift beliefs based on their perception, understanding and judgment of their veracity and outcomes, or involuntarily through pressure from their social groups. However, in general, people who were Christians tended to show less devotion to ancestors' worship and had doubts that human beings could have the power to stop the rain, crediting such powers instead to God. People who were illiterate or had lower levels of education showed the opposite.

As found in other studies, independently of the type of beliefs held, farmers generally see drought as a punishment from God or their ancestors for some unknown wrongdoing or shameful behavior. To justify the motives for punishment they find a variety of reasons that are driven by their context specific cultural beliefs. Nevertheless, these reasons remain underexplored in the literature and ignored in the adaptation context. The diversity of indigenous-related reasons outweighs the Christian-related reasons, and most participants did not have an explanation for their beliefs about God's punishment through drought; they just knew it was God because of His ability to control rain and to decide when it should or should not fall.

Although the indigenous-related reasons provided by participants from Chibuto and Guija belonged to the same categories presented in Table 2, participants from Guija presented more explanations as they follow more rituals than Chibuto (e.g., coupling and burying rituals). Nonetheless, participants gave a total of 18 explanations in the questionnaire and FGDs for their ancestors' infliction of punishment through drought, and the most predominant explanations were that the punishment was a result of unnecessary abortion by young people, and the failure to regularly perform traditional rain ceremonies, as had been done in the past. Yet, women presented more variety in their reasoning than men, as they showed themselves to be more observant and aware of happenings in their communities, and they placed greater emphasis on the importance of showing respect for their tradition.

While these most predominant reasons were static since they have been transmitted through the generations from ancestors to their descendants, the least predominant, but not least important, reasons were non-static, mutable, or circumstantial. The reasons were based on individual or group value-laden perceptions of what might be the negative, unexpected, wrong, or harmful things that have recently happened, or are currently happening, in their environment at local level (e.g., burying someone who had dreadlocks), 
or in some cases nationwide (e.g., war in the country). When people believe that the events could be avoided or prevented, they use them to attribute the blame for punishment through drought. They may attribute the blame to someone inside their community when they perceive that drought is not witchcraft-related, as they all depend on the rain for their activities and livelihoods. Otherwise, they may blame an outsider perceived as having suspicious and uncommon behaviors, and somehow benefiting from the lack of rain by not 'directly' depending on it for their activities.

The example given by farmers regarding the Indian food traders brings to attention how, in moments of distress, certain kinds of interventions can be misinterpreted, considered suspicious, not well received, and may create an opportunity to attribute blame for a negative event. This is especially the case if that distress comes from unknown or untrusted sources, even though the primary intention was to help farmers to survive. Trust plays an important role for farmers in ensuring a successful interaction and outcome of the intervention. For instance, during the same periods that the food traders intervened, the sale of improved seed at a subsidized price by the Government, a trusted body that often provides aid, was viewed as assistance. Farmers asserted that such assistance made it possible to cultivate after the end of drought, as they had consumed their saved seed after depleting food surpluses.

On the other hand, other examples given by farmers of 'effective' strategies for stopping drought, such as traditional ceremonies for abortion and exhumation of the person who had dreadlocks, showed how such 'perceived effectiveness' served to reinforce their indigenous beliefs about the causes of drought and to create new reasoning to justify the beliefs. Although these static and non-static beliefs and reasoning may serve to justify the occurrence of drought and help farmers live with its impacts, they may not reflect the real causal factors, and thus may lead farmers to underestimate their ability to control the environmental problems, which they see as within the domain of supernatural forces. Indeed, some studies about drought perceptions have related peoples' lack of appropriate adaptation to their perceived low capacity for control over environmental problems (Jones 2011; Slegers 2008). Generally, people are more motivated to engage in behaviors they consider feasible (Bandura 1997). At the same time, the importance of showing respect for their culture, or to be part of the community or social group (e.g., friends and religious groups) or perhaps fear of having some kind of reprisal from them, may lead farmers to have different answers about what constitutes their drought beliefs when individually and when in groups. Individually, farmers might be honest as they feel more comfortable and free to talk about their real beliefs, while in groups they might feel somehow 'pressured' to talk about what constitutes general thoughts, comments, or the beliefs of the community or their social groups (subjective norm). This normative behaviour is considered to be one of the social barriers to adaptation (Jones 2011).

Nevertheless, independently of farmers' underlying beliefs, it is important to bear in mind that they hold some kind of cultural belief about how the natural environment works, and this guides their understanding of the causes and risks of drought, and it influences their behavior and motivation to respond. However, as individuals continually check their own behavioral intentions against the actual or perceived intentions of significant others (Lalani et al. 2016), it is their perception of the social pressure they believe they are under to think and behave in accordance with those intentions which will dictate their choice of response. They may respond to drought, either individually or collectively, in a way that their significant others believe is most appropriate for the correction of the perceived wrongdoings for which the majority perceive they are responsible and accountable. Some examples are the performance of traditional rain ceremonies when the perceived punishment is related to their ancestors, or prayers to God when it is related to Christian beliefs. Such responses may constitute maladaptive strategies and lead farmers to greater vulnerability to drought events.

Murphy et al. (2016) contend that, globally, vulnerability tends to be higher in places where religion is predominant, which is the case in sub-Saharan Africa where Christianity is very important in daily life. In fact, findings have shown that, independent of age group, the majority of farmers are committed to Christianity and it plays a huge role in their personal lives and livelihood activities. According to farmers, churches not only represent God's house and a formal place in which to worship Him and ask for their needs, but they are also places where they make friends and gain a spiritual family, and learn to respect and live in harmony with each other. Churches are also places where they receive blessings for their lives and activities, and find emotional, physical, and financial support when needed, such as in the case of natural hazards, personal problems, funerals, and sickness in their family. Additionally, some churches such as Assembly of God and Zion are seen as places where diseases can be healed without the need to go to the hospital through the power of prayers. Some members stated that the hope of being cured from their long-term diseases was what drove them to start attending church. Thus, Kirkpatrick (2005, p. 5) contends that religion can be a powerful force in promoting mental health and improving social behavior and states of being.

Nonetheless, the majority of those claiming Christianrelated beliefs were female, even among married participants, i.e., 29 out of $48(60 \%)$ of the male participants responded as being Christians, while 117 out of $152(77 \%)$ women did so. Evidence from other studies has shown that, 
due to a combination of factors, women are more vulnerable to drought and other hazards than men (IFRC 2014, p. 21; Shackleton et al. 2015; Shahid and Behrawan 2008). In reality, women not only constitute the majority of Christians, but also the majority of the population, illiterate people and farmers in Gaza Province, and this scenario extends to the rest of the country. Women are also culturally responsible for deciding which crops to plant and when, according to the season, and are responsible for saving seeds for planting. On some occasions, to ease their decisions about crop choices, some women commented that they look at what others are doing in order to do the same, arguing that if the production fails everyone will fail together. This once again stresses the great influence of significant others on the farmers' agricultural choices, but specifically it stresses the important role women have concerning these choices, which may influence the adoption of seed varieties or crops that are drought resistant or tolerant.

Thus, all of the above explanations emphasise the importance of giving more focus to the influence of farmers' beliefs, reasonings, perceived capacity to adapt, and their social groups, on their decision-making processes, motivations to act, and responses to drought. As previously explained, caution should be taken when approaching farmers in order to avoid negative interactions and the outcomes of current or future intervention. On the other hand, as people's vast experiences and perceptions of the risks and impacts of drought on their agricultural activities, food security, and overall well-being is deemed to influence their behavior (van der Linden 2015), it seems clear that farmers' behavioral change will require more than their experience and perception of the risks. As farmers' responses are based more on the belief that drought is caused by supernatural forces, rather than their personal experience of drought and knowledge of its impacts, as stated by Deane (2009) and Leck et al. (2011), behavioral change will first require a clear knowledge of the causes of drought. Although this may not change farmers' worldviews about the natural environment, it may change the reasoning behind their beliefs for drought occurrence. However, extensive work will be required to achieve this.

Even though social groups, shifting beliefs, and trust in the Government may constitute opportunities for the transmission of scientific information to farmers, it is not the intention of this paper to suggest the kind of activities that should be undertaken to change farmers' beliefs, reasoning, or behavioral responses to drought. The expectation is that the insights gained into the socio-psychological factors that influence farmers' behavioral adaptation decisions in Gaza Province, Mozambique, will be useful to better understand farmers facing similar environmental and socio-psychological conditions elsewhere. However, sight should not be lost on the fact that cultural beliefs and reasoning are place-specific, thus each case should be considered independent and unique. Therefore, further context-specific investigations into the socio-psychological nature of farmers' beliefs will be required prior to intervention for more successful outcomes in helping farmers to respond to future drought risks.

Acknowledgements This study was funded by the Commonwealth Scholarship Commission (CSC) (Grant No. MZCS-2015-372) in the $\mathrm{UK}$, as part of a $\mathrm{PhD}$ Scholarship.

OpenAccess This article is distributed under the terms of the Creative Commons Attribution 4.0 International License (http://creativeco mmons.org/licenses/by/4.0/), which permits unrestricted use, distribution, and reproduction in any medium, provided you give appropriate credit to the original author(s) and the source, provide a link to the Creative Commons license, and indicate if changes were made.

\section{References}

Adger, W. N. 2003. Social capital, collective action, and adaptation to climate change. Economic Geography 79 (4): 387-404.

Adger, W. N., S. Agrawala, M. M. Q. Mirza, C. Conde, K. O’Brien, J. Pulhin, R. Pulwarty, B. Smit, and K. Takahashi. 2007. Assessment of adaptation practices, options, constraints and capacity. In Climate change 2007: Impacts, adaptation and vulnerability. Contribution of working group II to the fourth assessment report of the Intergovernmental Panel on Climate Change, eds. M. L. Parry, O. F. Canziani, J. P. Palutikof, P. J. van der Linden, and C. E. Hanson, 717-743. Cambridge: Cambridge University Press.

Adger, W. N., S. Dessai, M. Goulden, M. Hulme, I. Lorenzoni, D. R. Nelson, L. O. Naess, J. Wolf, and A. Wreford. 2009. Are there social limits to adaptation to climate change? Climatic Change 93 (3): 335-354.

Adger, W. N., J. Barnett, K. Brown, N. Marshall, and K. O'Brien. 2013. Cultural dimensions of climate change impacts and adaptation. Nature Climate Change 3 (2): 112-117.

Ariff, K. M., and K. S. Beng. 2006. Cultural health beliefs in a rural family practice: A Malaysian perspective. Australian Journal of Rural Health 14 (1): 2-8.

Artur, L., and D. Hilhorst. 2012. Everyday realities of climate change adaptation in Mozambique. Global Environmental Change 22 (2): 529-536.

Babane, M., and M. Chauke. 2015. The preservation of Xitsonga culture through rainmaking ritual: An interpretative approach. Studies of Tribes and Tribals 13 (2): 108-114.

Bandura, A. 1997. Self-efficacy: The exercise of control. New York: Freeman.

Bandura, A. 1998. Personal and collective efficacy in human adaptation and change. Advances in Psychological Science 1: 51-71.

Başgöz, I. 2007. Rain making ceremonies in Iran. Iranian Studies 40 (3): 385-403.

Benson, C., and E. J. Clay. 1998. The impact of drought on sub-Saharan African economies: A preliminary examination. Washington, DC: The World Bank.

Boillat, S., and F. Berkes. 2013. Perception and interpretation of climate change among Quechua farmers of Bolivia: Indigenous knowledge as a resource for adaptive capacity. Ecology and Society 18 (4): 21-33.

Brito, R., S. Famba, P. Munguambe, N. Ibraimo, and C. Julaia. 2009. Profile of the Limpopo basin in Mozambique: A contribution to 
the challenge program on water and food project No. 17. Maputo: FAEF-UEM.

Brooks, N. 2003. Vulnerability, risk and adaptation: A conceptual framework. Tyndall Centre for Climate Change Research Working Paper 38 (38): 1-16.

Campos, M., M. K. McCall, and M. González-Puente. 2014. Landusers' perceptions and adaptations to climate change in Mexico and Spain: Commonalities across cultural and geographical contexts. Regional Environmental Change 14 (2): 811-823.

Christian, N. G. 2014. The impact of climate change on African traditional religious practices. Journal of Earth Science and Climatic Change 5 (7): 1-5.

Deane, J. 2009. Least responsible, most affected, least informed: Public understanding of climate change in Africa. London, UK: BBC World Service Trust.

Dei, G. J. 1994. Indigenous African knowledge systems: Local traditions of sustainable forestry. Singapore Journal of Tropical Geography 14 (1): 28-41.

Devereux, S. 2007. The impact of droughts and floods on food security and policy options to alleviate negative effects. Agricultural Economics 37 (1): 47-58.

Farmer, J., L. Bourke, J. Taylor, J. V. Marley, J. Reid, S. Bracksley, and N. Johnson. 2012. Culture and rural health. Australian Journal of Rural Health 20 (5): 243-247.

Flick, U., and G. Gibbs. 2007. Analyzing qualitative data. Designing qualitative research. London, UK: Sage.

Fountain, P. M., S. L. Kindon, and W. E. Murray. 2004. Christianity, calamity, and culture: The involvement of Christian churches in the 1998 Aitape tsunami disaster relief. The Contemporary Pacific 16 (2): 321-355.

Gaillard, J. C. 2007. Resilience of traditional societies in facing natural hazards. Disaster Prevention and Management: An International Journal 16 (4): 522-544.

Golo, B. W. K., and J. A. Yaro. 2013. Reclaiming stewardship in Ghana: Religion and climate change. Nature and Culture 8 (3): 282-300.

Haluza-DeLay, R. 2014. Religion and climate change: Varieties in viewpoints and practices. Wiley Interdisciplinary Reviews: Climate Change 5 (2): 261-279.

Haruna, A. 1997. Rituals and ceremonies accompanying rainmaking. In L'homme et l'eau dans le bassin du lac Tchad: Man and water in the lake Chad basin, eds. H. Jungraithmayr, D. Barreteau, and U. Seibert, 227-240. Marseille: IRD Editions.

IFRC. 2014. World disaster report: Focus on culture and risk. http:// www.ifrc.org/world-disasters-report-2014. Accessed 20 June 2017.

INGC. 2009. Study on the impact of climate change on disaster risk in Mozambique: Synthesis report. http://www.mz.undp.org/content/ dam/mozambique/docs/Environment_and_Energy/INGC_Synth esis_Report_ClimateChange_Low-1.pdf. Accessed 15 March 2017.

IPCC. 2001. Third assessment report: Overview of impacts, adaptation, and vulnerability to climate change. https://www.ipcc.ch/ipccr eports/tar/wg2/pdf/wg2TARchap1.pdf. Accessed 19 May 2017.

IPCC. 2007. Fourth assessment report: Climate change 2007. https:// www.ipcc.ch/publications_and_data/ar4/wg2/en/annexessglossar y-a-d.html. Accessed 15 Feb 2018.

Jarawura, F. X. 2014. Perceptions of drought among rural farmers in the Savelugu district in the northern savannah of Ghana. Ghana Journal of Geography 6 (1): 102-120.

Johnson, D. D. 2005. God's punishment and public goods. Human Nature 16 (4): 410-446.

Johnson, D. 2016. God is watching you: How the fear of god makes us human. New York: Oxford University Press.
Jones, L. 2011. Social barriers to adaptation. In Overcoming barriers to climate change adaptation implementation in southern Africa, eds. L. Masters, and L. Duff, 41-60. Pretoria: Africa Institute of South Africa.

Kahan, D. M., D. Braman, J. Gastil, P. Slovic, and C. Mertz. 2007. Culture and identity-protective cognition: Explaining the whitemale effect in risk perception. Journal of Empirical Legal Studies 4 (3): 465-505.

Kahan, D. M., H. Jenkins-Smith, and D. Braman. 2011. Cultural cognition of scientific consensus. Journal of Risk Research 14 (2): $147-174$

Kahan, D. M., H. Jenkins-Smith, T. Tarantola, C. L. Silva, and D. Braman. 2015. Geoengineering and climate change polarization: Testing a two-channel model of science communication. The Annals of the American Academy of Political and Social Science 658 (1): 192-222.

Kirkpatrick, L. A. 2005. Attachment, evolution, and the psychology of religion. New York: Guilford Press.

Kuehne, G. 2014. How do farmers' climate change beliefs affect adaptation to climate change? Society \& Natural Resources 27 (5): 492-506.

Kumagai, Y., J. Edwards, and M. S. Carroll. 2006. Why are natural disasters not "natural" for victims? Environmental Impact Assessment Review 26 (1): 106-119.

Kyle, S. 2003. A brief overview of Mozambique's rural development and the role of US assistance (No. 2003-04). Staff Paper, Cornell University, Department of Applied Economics and Management.

Lalani, B., P. Dorward, G. Holloway, and E. Wauters. 2016. Smallholder farmers' motivations for using Conservation Agriculture and the roles of yield, labour and soil fertility in decision making. Agricultural Systems 146: 80-90.

Lebel, L. 2013. Local knowledge and adaptation to climate change in natural resource-based societies of the Asia-Pacific. Mitigation and Adaptation Strategies for Global Change 18 (7): 1057-1076.

Leck, H., C. Sutherland, D. Scott, and G. Oelofse. 2011. Social and cultural barriers to adaptation implementation. In Overcoming barriers to climate change adaptation implementation in southern Africa, eds. L. Masters, and L. Duff, 61-88. Pretoria: Africa Institute of South Africa.

Lewis, I. M., and J. B. Russel. 2016. Witchcraft. https://www.britannica .com/topic/witchcraft. Accessed 13 Nov 2017.

Mawere, M. 2011. African belief and knowledge systems: A critical perspective. Bomenda, Cameroon: African Books Collective.

Mbiti, J. S. 2015. Introduction to African religion. ILong Groove, IL: Waveland Press.

Meyer, B. 2004. Christianity in Africa: From African independent to pentecostal-charismatic churches. Annual Review of Anthropology 33: 447-474.

Ministério da Adminstracão Estatal (MAE). 2005. Perfil do distrito de Guija. http://www.portaldogoverno.gov.mz/por/content/download/ Guija.pdf. Accessed 30 Nov 2017.

Murphy, C., M. Tembo, A. Phiri, O. Yerokun, and B. Grummell. 2016 Adapting to climate change in shifting landscapes of belief. Climatic Change 134 (1): 101-114.

Ngara, R., and R. V. Mangizvo. 2013. Indigenous knowledge systems and the conservation of natural resources in the Shangwe community in Gokwe district, Zimbabwe. International Journal of Asian Social Science 3 (1): 20-28.

Oestigaard, T. 2005. Water and world religions: An introduction. Bergen: Centre for Development Studies, University of Bergen, SFU \& SMR Publisher.

Orlove, B., C. Roncoli, M. Kabugo, and A. Majugu. 2010. Indigenous climate knowledge in southern Uganda: The multiple components of a dynamic regional system. Climatic Change 100 (2): 243-265. 
Persson, J., N. E. Sahlin, and A. Wallin. 2015. Climate change, values, and the cultural cognition thesis. Environmental Science \& Policy 52: $1-5$.

Pew Forum. 2010. Tolerance and tension: Islam and Christianity in sub-Saharan Africa. http://www.pewforum.org/2010/04/15/ executive-summary-islam-and-christianity-in-sub-saharan-afric a/. Accessed 25 August 2017.

Robinson, L. W. 2009. Participatory development and the capacity of Gabra pastoralist communities to influence resilience. $\mathrm{PhD}$ dissertation. Faculty of Graduate Studies of The University of Manitoba. ProQuest Dissertations Publishing.

Roncoli, C., K. Ingram, and P. Kirshen. 2002. Reading the rains: Local knowledge and rainfall forecasting in Burkina Faso. Society \&Natural Resources 15 (5): 409-427.

Roncoli, C., T. Crane, and B. Orlove. 2009. Fielding climate change in cultural anthropology. In Anthropology and climate change: From encounters to actions, eds. S. A. Crate, and M. Nuttall, 87-115. San Francisco, CA: Left Coast Press.

Rouault, M., and Y. Richard. 2005. Intensity and spatial extent of droughts in southern Africa. Geophysical Research Letters 32 (15): L15702.

Rovere, R. L., T. Abdoulaye, G. Kostandini, Z. Guo, W. Mwangi, J. MacRobert, and J. Dixon. 2014. Economic, production, and poverty impacts of investing in maize tolerant to drought in Africa: An ex-Ante assessment. The Journal of Developing Areas 48 (1): 199-225.

Sanderson, S. K. 2008. Adaptation, evolution, and religion. Religion 38 (2): $141-156$

Schipper, E. L. F. 2010. Religion as an integral part of determining and reducing climate change and disaster risk: An agenda for research. In Der klimawandel, ed. M. Voss, 377-393. Basel: Springer.

Schipper, E. L. F. 2015. Religion and belief systems: Drivers of vulnerability, entry points for resilience building. In Culture and disasters: Understanding cultural framing of disaster risk reduction, eds. F. Kruger, G. Bankoff, T. Cannon, B. Orbwski and E. L. F. Schipper, 145-154. New York: Routledge.

Schipper, L., and J. Dekens. 2009. Understanding the role of culture in determining risk from natural hazards. IOP Conference Series: Earth and Environmental Science 6 (57): 572010.

Semenya, D. K. 2013. The making and prevention of rain amongst the Pedi tribe of South Africa: A pastoral response. HTS Theological Studies 69 (1): 1-5.

Shackleton, S., G. Ziervogel, S. Sallu, T. Gill, and P. Tschakert. 2015. Why is socially-just climate change adaptation in sub-Saharan Africa so challenging? A review of barriers identified from empirical cases. Wiley Interdisciplinary Reviews: Climate Change 6 (3): 321-344.

Shahid, S., and H. Behrawan. 2008. Drought risk assessment in the western part of Bangladesh. Natural Hazards 46 (3): 391-413.

Shaw, R., N. Uy, and J. Baumwoll. 2008. Indigenous knowledge for disaster risk reduction: Good practices and lessons learned from experiences in the Asia-Pacific Region. Bangkok: United Nations International Strategy for Disaster Reduction.

Sheil, D., R. Puri, M. Wan, I. Basuki, M. V. Heist, N. Liswanti, I. Rachmatika, and I. Samsoedin. 2006. Recognizing local people's priorities for tropical forest biodiversity. Ambio: A Journal of the Human Environment 35 (1): 17-24.

Slegers, M. F. 2008. If only it would rain": Farmers' perceptions of rainfall and drought in semi-arid central Tanzania. Journal of Arid Environments 72 (11): 2106-2123.

Slovic, P. E. 2000. The perception of risk. London, UK: Earthscan Publications.
Smit, B., and J. Wandel. 2006. Adaptation, adaptive capacity and vulnerability. Global Environmental Change 16 (3): 282-292.

Sumner, W. G. 2013. Folkways: A study of the sociological importance of usages, manners, customs, mores and morals. Redditch: Read Books Ltd.

Tambo, J. 2010. Adoption of agricultural technology in the context of climate change: The case of drought tolerant maize in north-east Nigeria. PhD dissertation. University of Copenhagen and Montpellier SupAgro.

Uaiene, R. N. 2008. Determinants of agricultural technical efficiency and technology adoption in Mozambique. PhD dissertation. Purdue University.

Udmale, P., Y. Ichikawa, S. Manandhar, H. Ishidaira, and A. S. Kiem. 2014. Farmers' perception of drought impacts, local adaptation and administrative mitigation measures in Maharashtra State, India. International Journal of Disaster Risk Reduction 10: 250-269.

UNESCO. 2015. Women's literacy in Angola and Mozambique. https ://uil.unesco.org/case-study/effective-practices-database-litba se-0/womens-literacy-angola-and-mozambique-mozambique. Accessed 10 Dec 2018.

van der Linden, S. 2015. The social-psychological determinants of climate change risk perceptions: Towards a comprehensive model. Journal of Environmental Psychology 41: 112-124.

Weese, J. R. 2016. Witchcraft in Africa. Anthropology symposium, Iowa State University, April 29.

Weller, S. C. 1998. Structured interviewing and questionnaire construction. In Handbook of methods in cultural anthropology, eds. $\mathrm{H}$. R. Bernard, and C. C. Gravlee, 365-409. London, UK: Rowman $\&$ Littlefield.

Wikman-Jorgensen, P. E., A. Morales-Cartagena, J. Llenas-García, T. M. Pérez-Porcuna, M. Hobbins, J. Ehmer, M. A. Mussa, R. Abellana, and C. Ascaso. 2015. Implementation challenges of a TB programme in rural northern mozambique: Evaluation of 2012 2013 outcomes. Pathogens and Global Health 109 (5): 221-227.

Wilhite, D. A., M. V. K. Sivakumar, and R. Pulwarty. 2014. Managing drought risk in a changing climate: The role of national drought policy. Weather and Climate Extremes 3: 4-13.

Wilson, J. P., and T. A. Moran. 1998. Psychological trauma: Posttraumatic stress disorder and spirituality. Journal of Psychology and Theology 26 (2): 168-178.

World Bank. 2013. What climate change means for Africa, Asia and the coastal poor. http://www.worldbank.org/en/news/featu re/2013/06/19/what-climate-change-means-africa-asia-coastalpoor. Accessed 6 Oct 2017.

Publisher's Note Springer Nature remains neutral with regard to jurisdictional claims in published maps and institutional affiliations.

Daniela Salite I have recently finished a doctoral study in Livelihoods (International and Rural Development) at the University of Reading, United Kingdom. My research was about "The role of cultural beliefs in shaping small-scale farmers' behavioral decisions to adapt to drought risks in Gaza Province - Southern Mozambique". I have also an honors degree in agricultural studies (Eduardo Mondlane University, Mozambique) and a master's degree in food security and agrifood systems (University of Queensland, Australia). 